\title{
PENINGKATAN KEMAMPUAN MENULIS BAHASA JEPANG MELALUI MODEL PEMBELAJARAN WORKSHOP
}

\author{
-Penelitian Tindakan pada Mahasiswa Program Studi Pendidikan Bahasa Jepang \\ FBS UNIMA-
}

\author{
Jourike Jeane Runtuwarouw \\ Program Studi Pendidikan Bahasa Jepang, Universitas Negeri Manado \\ Jl. Tondano, Koya, Tondano Sel., Sulawesi Utara \\ e-mail: runtuwarouwjourike@gmail.com
}

First received: 24 November 2017

Final proof received: 31 December 2017

\begin{abstract}
Abstrak
Penelitian ini bertujuan untuk meningkatkan kemampuan menulis mahasiswa/i Program Studi Pendidikan Bahasa Jepang, Fakultas Bahasa dan Seni, Universitas Negeri Manado, melalui model pembelajaran workshop dan kolaborasi. Metode penelitian yang digunakan yaitu model penelitian tindakan dari Kemmis dan Imc Taggart yang terdiri dari tiga tahapan yaitu perencanaan tindakan, tindakan dan observasi/refleksi. Penelitian ini dilaksanankan dalam tiga siklus. Subyek penelitian ini yaitu mahasiswa/i program studi pendidikan bahasa Jepang FBS UNIMA semester lima, tahun ajaran 2016/2017. Data penelitian diambil dari berbagai sumber melalui beberapa teknik pengumpulan data yaitu observasi, wawancara, tes. Data diolah secara manual dengan prinsip panduan metodologi kualitatif dan kuantitatif. Melalui penjaminan mutu kualitas data (triangulasi) dan prosesnya dilakukan dalam interpretasi yang ketat, penelitian ini menemukan beberapa hal berikut. Hasil penelitian selama tiga siklus menunjukkan peningkatan nilai rata-rata kemampuan menulis siswa melalui workshop dan model kolaborasi di setiap akhir pengujian. Hasil pretest kemampuan menulis sakubun siswa menunjukkan nilai rata-rata 48,06\%, tes pada akhir siklus pertama menunjukkan nilai ratarata $53,06 \%$, tes pada akhir siklus kedua menunjukkan nilai rata-rata $68,47 \%$, dan tes pada akhir siklus ketiga menunjukkan rata-rata rata-rata $82,11 \%$. Berdasarkan indikator keberhasilan nilai rata-rata tes siswa pada akhir siklus ketiga yang mencapai $82,11 \%$ menunjukkan bahwa dengan menggunakan kolaborasi dan lokakarya pembelajaran sakubun dapat meningkatkan kemampuan menulis mata pelajaran siswa.
\end{abstract}

\begin{abstract}
This study aims to improve writing to student in the Course of Study of Japanese Language Education in Faculty of Languages and Arts at Manado State University through the workshops and collaborations the learning model. The method used was the action research model of Kemmis and Mc Taggart which consists of three phases, namely, action planning, action and observation/reflection. This research was conducted in three cycles. The subject of this study is the fifth semester with students of Japanese language education. FBS UNIMA 2015/2016. Research data was taken from various sources through multiple data collection techniques are observations, interviews, tests. The data was processed manually with the guiding principles of qualitative and quantitative being methodologies. Through quality assurance of data quality (triangulation) and the process is carried out in strict interpretation, this study found the following. The results of the study during three cycles showed an increase in the average value of student's writing skills through the workshops and collaborations model in each end of the test .The results of the pretest of student sakubun
\end{abstract}


writing ability shows an average value of $48.06 \%$, the test at the end of the first cycle shows the average value of $53.06 \%$, a test at the end of the second cycle showed an average value of $68.47 \%$, and the test at the end of the third cycle shows the average average $82.11 \%$. Based on the success indicators of the average test scores of students at the end of the third cycle which reaches $82.11 \%$ indicates that using collaborations and workshops in the learning of writing sakubun can improve student's sakubun writing skills.

\section{Keywords : ability, writing sakubun, workshop learning model.}

PENDAHULUAN

Kemampuan menulis selama ini diyakini sebagai sumbu atau pusat pembelajaran bahasa. Melalui kegiatan manulis, kemampuan bahasa seseorang akan sangat mudah diketahui. Dalam urut keterampilan bahasa, menulis ditempatkan pada posisi terakhir, karena menurut beberapa penelitian menulis merupakan keterampilan berbahasa paling tinggi sekaligus paling langka digunakan dalam komunikasi berbahasa para mahasiswa. Berbagai kenyataan yang mendukung opini dan argumentasi di atas bermuara pada rendahnya kemampuan menulis mahasiswa (Anshori, 2004: 1).

Menulis adalah salah satu keterampilan berbahasa yang merupakan aplikasi dari penguasaan kosakata, tata bahasa, dan huruf, ketika akan menuangkan ide dan gagasan secara tertulis.

Keterampilan menulis memiliki tingkat kompleksitas yang cukup tinggi. Kegiatan menulis baru dapat terlaksana setelah manusia "belajar" dahulu mengenai bahasa tertulis karena keterampilan ini berbeda dengan keterampilan menyimak dan berbicara yang dimiliki manusia normal sejak lahir. Dengan kata lain, menulis merupakan keterampilan berbahasa yang tidak sederhana.

Kesulitan dalam menulis diakui oleh berbagai pihak. Nurgiyantoro dan Alwasilah mengakui bahwa kemampuan menulis lebih sulit dikuasai dibandingkan dengan ketiga kemampuan berbahasa lainnya, sekalipun oleh penutur asli. Hal itu disebabkan oleh kemampuan menulis menghendaki penguasaan berbagai unsur kebahasaan dan unsur di luar bahasa yang akan menjadi isi tulisan.

Berdasarkan temuan tersebut ada dua hal subtansial yang dapat dicermati yaitu bahwa koreksi dari pihak dosen atas tulisan mahasiswa yang ditugaskannya sangat penting guna mengetahui dan mengukur tulisan mahasiswa; dan di perguruan tinggi pun ternyata teori tentang menulis lebih banyak diberikan ketimbang praktik, padahal untuk jenjang perguruan tinggi dapat dipastikan mahasiswa relatif telah "menguasai' teori tentang menulis. 
Sementara itu, kendala internal dari mahasiswa yaitu kurang menyadari pentingnya menulis, dan faktor eksternal, yakni tentang kompetensi pengajar (dosen) juga turut andil memperparah rendahnya keterampilan menulis mahasiswa.

Dalam rangka mengatasi masalah di atas, diperlukan sebuah model pembelajaran yang memungkinkan dapat diminimalisasi masalah-masalah di atas. Salah satu model pembelajaran yang diduga dapat mengaktifkan proses pembelajaran menulis sakubun adalah model pembelajaran workshop. Model workshop mengasumsikan bahwa setiap mahasiswa harus melakukan aktivitas sesuai dengan kecakapannya masingmasing dan berperan aktif (langsung) dalam setiap sesi pembelajaran. Melalui model ini akan didapati gambaran tentang faktor-faktor dominan yang mempengaruhi kemajuan menulis sakubun para mahasiswa sehingga staf pengajar akan melakukan terapi terhadap para mahasiswa yang memiliki kemampuan menulis rendah. Dengan model workshop menulis mampu mengukur kemajuan menulis para mahasiswa secara individual dan diperbandingkan antara mahasiswa yang satu dengan mahasiswa yang lainnya.

Selanjutnya, workshop menulis seperti yang pernah dilakukan Alwasilah menghasilkan beberapa temuan, diantaranya menyadarkan mahasiswa akan kompleksitas proses menulis, inovatif, integratif, dan efektif untuk berlatih menulis dan lebih berkosentrasi pada proses menulis. Selain itu, melalui workshop menulis mahasiswa terdorong untuk menulis secara professional, dan adanya feedback karena dalam workshop hasil tulisan mahasiswa benar-benar dikoreksi.

Hal tersebut di atas dipertegas oleh Tiedt bahwa melalui workshop juga dapat dibentuk tanggung jawab untuk masingmasing pelajar dalam bekerja sama. Model ini menekankan kegiatan berlatih dan bekerja sama dalam kelompok-kelompok kecil secara kolaboratif. Dalam model ini mahasiswa belajar bersama, saling membantu dan berdiskusi bersama-sama dalam menyelesaikan suatu kegiatan belajar. Selanjutnya Killen mengemukakan bahwa model pembelajaran kolaborasi merupakan model pembelajaran yang mendorong para pembelajar untuk bekerja sama dan untuk memaksimalkan belajar mereka dan belajar dengan temannya.

Berdasarkan beberapa temuan penelitian tersebut dapat diasumsikan bahwa model pembelajaran kolaborasi lebih dari sekedar belajar kelompok atau kerja kelompok karena dalam pembelajaran kolaborasi ada struktur 
dorongan dan tugas yang bersifat kolaboratif, sehingga memungkinkan terjadinya interaksi secara terbuka dan yang efektif diantara anggota kelompok. Melalui model pembelajaran workshop yang dipadukan dengan model pembelajaran kolaborasi diharapkan dapat mengatasi permasalahan yang terjadi dalam proses pembelajaran menulis sakubun.

Model pembelajaran menulis sakubun melalui workshop yang diterapkan dalam penelitian ini menekankan pada adanya aktivitas dan interaksi di antara mahasiswa, untuk saling memotivasi dan membantu dalam menguasai materi pelajaran, dalam hal ini keterampilan menulis sakubun.

Latar belakang di atas, mendorong untuk diadakan penelitian tindakan yang bertumpu pada Peningkatan Kemampuan Menulis Bahasa Jepang (Sakubun) melalui Model Workshop. (Penelitian Tindakan pada Mahasiswa Program Studi Pendidikan Bahasa Jepang Fakultas Bahasa dan Seni Unima).

Berdasarkan latar belakang dan identifikasi masalah maka fokus utama penelitian tindakan ini adalah peningkatan kemampuan menulis bahasa Jepang (sakubun) mahasiswa program studi pendidikan bahasa Jepang Unima melalui model pembelajaran workshop yakni kemampuan menemukan dan mengembangkan ide/gagasan menulis permulaan sakubun dimulai dengan berlatih menulis dari penguasaan kosa kata, penguasaan huruf (kana dan kanji), pola kalimat, ungkapan dan kaidah-kaidah gramatika yang berlaku dalam bahasa Jepang, kemampuan mengorganisasi isi karangan berdasarkan alur tertentu yg sesuai dengan budaya bahasa Jepang, relevansi antara tema dan isi karangan. Dengan pendekatan proses melalui model pembelajaran workshop yang menekankan kegiatan berlatih dan bekerja sama dalam kelompok-kelompok kecil 2528 secara kolaboratif sehingga memungkinkan terjadinya interaksi secara terbuka dan yang efektif di antara anggota kelompok.

Selanjutnya fokus masalah tersebut dijabarkan pada sub fokus penelitiannya sebagai berikut: 1) proses peningkatan kemampuan menulis bahasa Jepang (sakubun) melalui model pembelajaran workshop, dan 2) hasil peningkatan bahasa Jepang (sakubun) melalui model pembelajaran workshop.

Berdasarkan fokus dan subfokus di atas maka dapat dirumuskan masalah penelitian sebagai berikut: 1) Bagaimanakah proses peningkatan bahasa Jepang (sakubun) melalui model workshop? 2) Apakah kemampuan 
menulis (sakubun) dapat ditingkatkan melalui model workshop?

\section{KAJIAN TEORI}

Penelitian tindakan (action research) pertama kali diperkenalkan oleh ahli psikologi Amerika yang bernama Kurt Lewin pada tahun 1946. Inti gagasan Lewin inilah selanjutnya dikembangkan oleh ahli-ahli lain seperti Stephen Kemmis, Robin McTaggart, Jhon Eliot, Dave Ebbutt, dan sebagainya.

Penelitian tindakan adalah yaitu studi sistematis upaya meningkatkan praktik pendidikan kelompok partisipan dengan cara melakukan tindakan praktis dan merefleksi sendiri terhadap pengaruh tindakan tersebut (Emzir, 2008: 234).

Suhardjono dalam Arikunto (2006:56) menjelaskan bahwa penelitian tindakan (action research) yang dilakukan dengan tujuan memperbaiki mutu praktik pembelajaran di kelas, berfokus pada kelas atau pada proses belajar mengajar yang terjadi di kelas bukan pada input kelas (silabus, materi, dan lain-lain) ataupun pada output (hasil belajar).

$$
\text { Menurut Elliot (1991: }
$$

penelitian tindakan merupakan kajian situasi sosial yang bertujuan untuk peningkatan. Proses penelitian dimulai dari telaah, perencanaan, pelaksanaan, pemantauan pengaruh penciptaan hubungan yang diperlukan antara evaluasi diri dan perkembangan professional.

Kemmis dan McTaggart (1988: 58) menggunakan terma penelitian tindakan kolaboratif dari penelitian tindakan partisipatori (PAR) untuk menamai penelitian tindakan ini. Keduanya menjelaskan bahwa ruang lingkup garapan penelitian tindakan ini luas, meliputi bidang pekerjaan sosial, pendidikan, dunia industri dengan menggunakan pendekatan yang beragam. Seluruh prosesnya telaah, diagnosis, perencanaan, pemantauan, dan pengaruh menciptakan hubungan yang diperlukan antara evaluasi diri dan perkembangan professional. Penelitian tindakan adalah suatu bentuk refleksi diri kolektif yang dilakukan oleh pesertapesertanya dalam situasi sosial untuk meningkatkan penalaran dan keadilan praktik-praktik itu terhadap situasi tempat dilakukan praktik-praktik tersebut.

\section{Kemampuan Menulis Bahasa Jepang (Sakubun)}

Kemampuan merupakan karakteristik umum yang berkaitan dengan pengetahuan dan keterampilan yang dimiliki seseorang yang diwujudkan melalui tindakan dan mengarah pada peningkatan kinerja. (Rusman,2011:78). 
Selanjutnya Sternberg (1994: 3), dikemukakan oleh Chomsky yang menyatakan bahwa kemampuan adalah kekuatan untuk menunjukkan suatu tindakan khusus baik secara fisik, maupun secara mental.

Menurut Chaplin (2000:1), ability (kemampuan, kecakapan, ketangkasan, bakat, kesanggupan) merupakan tenaga (daya kekuatan melakukan suatu perbuatan. Para ahli mengatakan bahwa kemampuan adalah kecakapan, ketangkasan, bakat, kesanggupan, tenaga (daya kekuatan) untuk melakukan suatu kegiatan fisik, perbuatan.

Dari beberapa pendapat di atas, disimpulkan bahwa kemampuan adalah kesanggupan atau kecakapan dalam menghasilkan atau melakukan sesuatu untuk mencapai tujuannya sesuai dengan kondisi yang diharapkan.

Berbicara tentang kemampuan tidak tepat kalau tidak dihubungkan dengan kemampuan berbahasa. Kemampuan berbahasa merupakan kesanggupan menggunakan bahasa untuk menyampaikan suatu maksud kepada orang lain serta maksud yang disampaikan oleh orang lain dalam suatu peristiwa komunikasi.

Sehubungan dengan kemampuan berbahasa tersebut, dikenal dua istilah, yaitu (1) kompetensi; dan (2) performansi. Konsep 'kompetensi dan 'performansi' mengatakan bahwa kompetensi adalah pengetahuan mendasar tentang sistem bahasa, kaidah-kaidah tata bahasa, kosakatanya, seluruh pernak-pernik bahasa dan bagaimana menggunakannya secara terpadu. Performansi adalah produksi aktual (berbicara, menulis atau pemahaman (menyimak, membaca merupakan manifestasi pemakaian bahasa oleh seseorang dalam situasi yang konkret (Brown, 2008: 38-39).

Berdasarkan uraian di atas, dapat disimpulkan bahwa kemampuan berbahasa adalah kesanggupan berkomunikasi yang meliputi kesanggupan mewujudkan penguasaan kaidah-kaidah dalam bahasa yang telah diketahui (kompetensi) ke dalam $\triangle$ GA wujud $B A$ pemakaian bahasa (performasi) untuk mencapai tujuan komunikasi.

Menulis dalam karya tulis ini sama dengan mengarang. Hal ini sejalan dengan pendapat The Liang Gie bahwa, menulis merupakan padanan kata mengarang. Sinonim itu, diipakai sebagai selang-seling untuk mencegah kesenadaan (Bloom, 1979). Selanjutnya Liang Gie menyatakan bahwa menulis adalah keseluruhan rangkaian kegiatan seseorang dalam mengungkapkan gagasan dan menyampaikan bahasa tulis kepada 
pembaca untuk dipahami dan dimengerti oleh orang lain.

Sokolik (2008: 98) mengatakan bahwa menulis adalah kombinasi antara proses dan produk. Prosesnya yaitu pada saat mengumpulkan ide-ide sehingga tercipta tulisan yang dapat terbaca oleh pembaca yang merupakan produk dari kegiatan yang dilakukan penulis.

Kata "Sakubun" sendiri, dalam kamus karya Kenji Matsura diterjemahkan sebagai penulisan karangan. Sakubun yaitu membuat kalimat mengenai suatu hal (Kidaichi, 1997: 533). Kalau melihat pengertian tersebut dan membandingkannya dengan huruf- huruf yang terdapat dalam kata tersebut, sakubun terdiri dari dua huruf yaitu saku yang berarti membuat dan bun yang berarti kalimat. Menulis sendiri dalam bahasa Jepang yaitu kaku.

Batasan menulis dalam konteks kemampuan berbahasa Jepang bukan hanya berhubungan dengan menghasilkan huruf pada suatu bidang, namun juga berhubungan dengan kegiatan mengarang. Mengarang sendiri menurut Suadi (2007: 2) adalah proses mengemukakan/menyusun pendapat, sedangkan menulis adalah proses membuat pendapat tersebut dalam bentuk tertulis.

Dengan demikian, dapat disimpulkan bahwa menulis adalah kegiatan mengekspresikan ide, gagasan atau pikiran yang diungkapkan melalui huruf dalam bentuk kalimat.

\section{Model Pembelajaran}

Model pembelajaran dapat diartikan sebagai kerangka konseptual yang melukiskan prosedur sistematika mengorganisasikan pengalaman belajar untuk mencapai tujuan belajar tertentu, dan berfungsi sebagai pedoman bagi para perancang pembelajaran dan para guru untuk merencanakan dan melaksanakan aktivitas-aktivitas pembelajaran. Model pembelajaran juga dapat dimaknai sebagai perangkat rencana atau pola yang dapat dipergunakan untuk merancang bahanbahan pembelajaran serta membimbing aktivitas pembelajaran di kelas atau di tempat-tempat lain yang melaksanakan aktivitas-aktivitas pembelajaran (Aunnurahman, 2009: 146).

Pembelajaran menulis bahasa
Jepang (sakubun) harus mampu
menggiring mahasiswa untuk belajar
menulis sakubun melalui proses menulis.
Bukan berarti teori menulis tidak perlu
melainkan jangan terlalu dominan
mengingat menulis merupakan suatu
keterampilan, jadi latihan/praktik harus di
utamakan. Hal penting lainnya adalah
bagaimana agar pembelajaran menulis
bagaimana agar pembelajaran menulis 
sakubun benar-benar menjadi laboratorium menulis bagi para mahasiswa.

Untuk itu perlu dikembangkan model pembelajaran menulis berdasarkan pendekatan tertentu, sehingga memungkinkan pembelajar (mahasiswa) lebih banyak menggunakan bahasa daripada menguasai teori bahasa semata. Hal ini sangat penting guna mencari solusi atas "kegagalan" pembelajaran menulis di semua jenjang, termasuk di perguruan tinggi.

Salah satu pendekatan proses yang diduga dapat mengaktifkan proses pembelajaran menulis bahasa Jepang (sakubun) adalah model pembelajaran workshop dan kolaborasi yang dikemas dalam satu kesatuan model pembelajaran inovatif oleh peneliti.

Hakikat workshop yaitu kegiatan praktek yang lebih banyak latihan menulis daripada teori. Oleh karena itu, workshop menulis diarahkan kepada kegiatan praktek menulis, mengoreksi, mendiskusikan hasil tulisan, berkolaborasi, dan memperbaikinya. Walaupun demikian, unsur teori tetap tidak dapat dihilangkan sama sekali karena ketika kita mengoreksi tulisan, misalnya dari aspek tata bahasa, maka baik pihak yang mengoreksi maupun pihak yang dikoreksi masing-masing harus memiliki bekal kemampuan tentang ketatabahasaan. Dengan demikian, akan terjadi proses interaksi yang seimbang ketika melakukan diskusi, kolaborasi dan sebagainya.

Workshop sangat cocok untuk kegiatan menulis karena lebih terpusat kepada pembelajar daripada pengajar/instruktur sehingga hasil belajar lebih efektif. Hal ini seperti dijelaskan Tied sebagai berikut: "an effective writing program is student-centered".

Dengan workshop pembelajar dituntut aktif, mulai dari persiapan (prewriting), penyusunan draf kasar (drafting), merevisi tulisan (revising), melakukan penyuntingan 2 (editing), berbagi dengan teman dengan saling memeriksa tulisan (sharing), penulisan kembali tulisan dan mengumumkannya kepada $\subseteq A$ teman-teman (publishing) dan dilakukan dalam tiga kategori kegiatan yang dimulai dari kegiatan: 1) Minilesson: pengajar memberikan petunjuk tentang menulis kepada siswa. 2) Writing time and conference: pengajar mengarahkan siswa untuk mulai menyusun draf kasar merevisi dan menyunting. 3) Sharing time: berdiskusi dengan teman atau kelompok kecil, saling membaca karya tulis masing-masing.

Model workshop mengasumsi-kan bahwa setiap mahasiswa harus melakukan aktivitas sesuai dengan kecakapannya masing-masing dan berperan aktif 
(langsung) dalam setiap sesi pembelajaran. Melalui wokrshop juga dapat dibentuk tanggung jawab untuk masing-masing pelajar dalam bekerja sama (Tiedt, 1989).

Pembelajaran menulis sakubun melalui model workshop yang diterapkan dalam penelitian ini menekankan pada adanya kerjasama dan interaksi di antara mahasiswa, untuk saling memotivasi dan membantu dalam menguasai materi pelajaran, dalam hal ini keterampilan menulis sakubun.

Dalam model ini mahasiswa belajar bersama, saling membantu dan berdiskusi bersama-sama dalam menyelesaikan suatu kegiatan belajar.model pembelajaran kolaborasi lebih dari sekedar belajar kelompok atau kerja kelompok karena dalam pembelajaran kolaborasi ada struktur dorongan dan tugas yang bersifat kolaboratif, sehingga memungkinkan terjadinya interaksi secara terbuka dan yang efektif diantara anggota kelompok.

Berdasarkan kerangka teoretik di atas diduga bahwa model pembelajaran terpadu workshop dapat meningkatkan kemampuan menulis bahasa Jepang (sakubun) mahasiswa program studi pendidikan bahasa Jepang Unima.

Hipotesis penelitian tindakan ini adalah sebagai berikut:
Jika diterapkan model pembelajaran terpadu workshop, maka kemampuan menulis bahasa Jepang (sakubun) mahasiswa program studi pendidikan bahasa Jepang Unima akan meningkat.

\section{METODE PENELITIAN}

Tujuan penelitian: 1) Mengetahui proses peningkatan kemampuan menulis sakubun melalui workshop

2) Mengetahui hasil peningkatan kemampuan menulis sakubun melalui workshop

Penelitian tindakan

(Action Research) telah dilaksanakan di program studi pendidikan Bahasa Jepang Fakultas Bahasa dan Seni Universitas Negeri Manado pada semester $\mathrm{V}$ Tahun Akademik 2015-2016, dimulai bulan September hingga bulan Januari 2015. Penelitian dilaksanakan selama satu semester pada saat proses pembelajaran Mata Kuliah Sakubun.

Penelitian ini menggunakan rancangan metode penelitian tindakan (action research). Penggunaan penelitian tindakan dalam penelitian ini relevan dengan permasalahan yang dihadapi. Seperti telah dikemukakan di bagian latar belakang penelitian, bahwa masalah dalam penelitian ini muncul dari praktik pembelajaran sehari-hari yang dirasakan 
langsung oleh dosen dan mahasiswa di dalam kelas, yaitu masalah pembelajaran menulis sakubun pada mahasiswa program pendidikan FBS Unima.

Penelitian tindakan yang digunakan bersifat kualitatif karena peneliti berinteraksi dengan subjek penelitian secara alamiah, adalam arti peneliti berjalan sesuai dengan jalannya proses belajar mengajar, dengan cara mengadakan pengamatan, melakukan penelitian secara sistematis, dan menarik kesimpulan sebagaimana layaknya dilakukan oleh peneliti kualitatif. Pengajar selaku peneliti sepenuhnya selama proses penelitian berjalan, sambil mengamati langsung, menanggapi respon subjek penelitian dan masukan dari kolaborator peneliti berupaya untuk memperbaiki atau merevisi rencana tindakan selanjutnya. Peneliti dalam penelitian ini berperan sebagai pelaksana sekaligus pengamat penelitian atau active participant observer. Dalam hal ini peneliti bertindak sebagai pelaksana tindakan sekaligus sebagai observer yang mengamati tindakan tersebut dan sebagai pelaksanan tindakan. Hal ini dilakukan sebagai upaya menciptakan situasi yang natural dan lebih objektif dalam penelitian tindakan yang dilakukan. Penelitian tindakan bersifat partisipatif dalam arti bahwa peneliti terlibat dalam penelitian, dan bersifat kolaboratif karena melibatkan pihak lain (kolaborator) dalam penelitian. Dengan keterbukaan diri terhadap kritik dan masukan dari kolaborator, peneliti mengetahui hai-hal yang perlu diubah dan ditingkatkan.

Kuantitatif digunakan untuk menganalisis data hasil proses belajar mengajar atau membandingkan nilai siswa sebelum dan sesudah penelitian tindakan dilakukan. Nilai akan diuji kebenarannya melalui metode tersebut untuk melihat seberapa besar signifikannya nilai sebelum dan sesudah dilakukan tindakan.

Desain penelitian tindakan yang digunakan dalam penelitian ini adalah model Kemmis dan McTaggart. Alasan pemilihan model ini adalah berdasarkan kesederhanaan $B$ prosedur AN kerja dan pandangan terhadap penelitian tindakan, bahwa penelitian tindakan itu dilakukan berdasarkan adanya ide untuk melakukan perubahan dan peningkatan dari suatu kondisi yang lebih baik atau lebih maju. Model penelitian tindakan ini terdiri atas 3 tahap yaitu, 1) perencanaan tindakan (planning), 2) pelaksanaan tindakan (acting) dan pengamatan(observing), 3) refkeksi (reflecting). Disatukannya tahap pelaksanaan tindakan (acting) dan pengamatan (observing) dikarenakan adanya kenyataan bahwa implementasi kedua tahap tersebut tidak dapat 
dipisahkan. Dengan kata lain keduanya dilakukan dalam satu kesatuan waktu. Ketika tindakan dilakukan observasi pun dilaksanakan.

Seluruh kegiatan tindakan penelitian harus senantiasa di amati atau dilakukan pematauan secara saksama sekaligus melakukan pengamatan, baik pada desain pembelajaran maupun pada perkembangan kemampuan menulis sakubun mahasiswa. Pengamatan dilakukan oleh peneliti atau teman sejawat. Peneliti selain mengajar dan melaksanakan tindakan penelitian dengan menerapkan model workshop dan kolaborasi juga bertugas mengamati halhal yang terjadi di kelas yakni 'memperhatikan' proses pembelajaran dan tanggapan serta kemampuan mahasiswa dalam mengikuti pembelajaran,juga mengamati dan mencatat hasil perkembangan kemampuan menulis sakubun mahasiswa setelah melakukan langkah kaji tindak.Hasil obsevasi merupakan kesimpulan dari pelbagai pengamatan secara saksama terhadap hasil belajar mahasiswa selama pembelajaran sakubun berlangsung. Selain itu, peneliti juga memberikan penilaian terhadap latihan-latiahan dan tugas yang dikerjakan mahasiswa. Bahkan, peneliti pun mencatat perkembangan kemampuan dan nilai mahasiswa dalam setiap pertemuan dan siklus.
Hasil pengamatan yang diperoleh selama berlangsungnya kegiatan pembelajaran melalui workshop dan kolaborasi dianalisis. Berdasarkan hasil analisis ini, peneliti dengan teman sejawat melakukan refleksi untuk menyiapkan hasil penelitian dan merencanakan langkah berikutnya. Refleksi ini mencakup keseluruhan aspek pembelajaran yang didasarkan pada catatan peneliti serta tanggapan mahasiswa mengenai tindakan pembelajaran menulis sakubun melalui workshop. Hal-hal yang kurang disetiap pertemuan diperbaiki sedangkan yang sudah baik ditingkatkan pada pertemuan berikutnya untuk mencapai peningkatan hasil yang maksimal.

Hasil yang diperoleh pada siklus 1 dijadikan acuan atau rujukan dalam menentukan kegiatan siklus 2 sehingga kegiatan penelitian tindakan dapat dilaksanakan secara berkesinambungan dan memiliki keterkaitan yang tinggi. Ini dilakukan agar mendapat hasil penelitian yang valid sehingga indikator keberhasilan yang telah ditetapkan dapat dicapai secara optimal. Kelemahan-kelemahan itu dibahas bersama kolaborator, kemudian menyusun perencanaan pada siklus kedua. Demikian seterusnya, hingga apa yang telah direncanakan dalam skenario pembelajaran pada penelitian tindakan dapat tercapai 
Penelitian tindakan ini

dilaksanakan dalam tiga siklus, yaitu untuk meningkatkan kemampuan menulis sakubun mahasiswa. Siklus pertamapada tahap pelaksanaan tindakan terbagi atas enam tahap dan siklus kedua terbagi atas empat tahap yang dimulai dari tahap ke tiga sampai tahap keenam.

Adapun tahap-tahap yang dilakukan pada pelaksanaan penelitian tindakan yang bertumpu pada peningkatan kemampuan menulis bahasa Jepang (sakubun) melalui model pembelajaran workshop.

Teknik analisis data dalam penelitian ini mengacu pada langkahlangkah analisis yang telah baku dalam penelitian tindakan. Secara umum teknik analisis data dalam penelitian tindakan mencakup langkah-langkah berikut: Mengoleksi data, Memvalitasi hipotesis tindakan, Menginterpretasi data, Merencanakan tindakan selanjutnya (Depdikbud, 1999:42).

\section{HASIL DAN PEMBAHASAN}

\section{Hasil}

Berdasarkan penelitian tindakan pada peningkatan kemampuan menulis bahasa Jepang (sakubun) melalui model pembelajaran workshop maka diperoleh temuan penelitian dalam ketiga siklus. Adapun temuan penelitian tersebut disimpulkan berdasarkan sumber data kualitatif dari hasil pengamatan proses pembelajaran yang dilaksanakan pada setiap pertemuan pembelajaran dari siklus pertama sampai siklus ketiga.

Pada tes asal pretes ada dua orang mahasiswa dengan kriteria tinggi sebesar 5,50\%, 12 mahasiswa dengan kriteria sedang 33,33\% dan 22 mahasiswa dengan kriteria rendah $61,11 \%$.

Pada siklus pertama kriteria observasi yang mencapai kriteria tinggi sebesar 11,11\% (4 mahasiswa), kriteria sedang 41,67\% (15 mahasiswa), dan kritria rendah 17 mahasiswa sebesar $47,22 \%$.

Pada siklus kedua diperoleh data mengenai proses pembelajaran sebagai berikut, kriteria tinggi sebesar 19,49\% (7 orang mahasiswa), kriteria sedang ada 21 orang mahasiswa sebesar 58,33\% dan kriteria rendah 8 mahasiswa sebesar $22,22 \%$.

Pada siklus ketiga 9 orang mahasiswa dengan kriteria tinggi sebesar 25\%, 25 orang mahasiswa sebesar $69,44 \%$ dan kriteria rendah sebesar $5,56 \&$ (2 orang mahasiswa).

Berikut ini adalah respon peneliti dan kolaborator terhadap pengamatan mahasiswa dalam proses pembelajaran selama tiga siklus: 1) Peningkatan kemampuan mahasiswa dalam membuat karangan, terjadi juga pada tiap siklus. 
Meskipun pada umumnya masih berkategori memuaskan, namun telah terjadi kenaikan yang signifikan pada ratarata nilai dari pretes, siklus I, siklus II, dan siklus III. 2) Komponen kerja sama tim yang diamati selama proses pembelajaran Nampak bahwa mahasiswa telah dapat menulis sakubun dengan baik dan mengutamakan proses kerja sama 'tim' uang sangat baik ketika pengerjaan tugas kelompok. Dari siklus pertama sampai siklus ketiga rerata skor untuk komponen ini di atas. Itupun secara keseluruhan, komponen tersbut mengalami peningkatan yang tinggi dari siklus ke siklus. Hal ini dibuktikan dari rerata skor yang pada umumnya menunjukkan kerja sama yang sangat tinggi. Dengan kata lain selama pelaksanaan pembelajaran menulis sakubun melalui model pembelajaran workshop dan kolaborasi, kerja sama mahasiswa menunjukkan criteria tinggi. Proses kerja sama dalam kelompok lebih hidup karena setiap komponen telah memahami peran dan tanggung jawabnya. 3) Pada komponen kemandirian nampak kemandirian mahasiswa dalam kelompok semakin mantap karena dosen memberi bimbingan secara proporsional. Motivasi mahasiswa untuk berprestasi meningkat karena ada nuansa perlombaan antar kelompok dan suasana pembelajaran yang demikian kondusif memberikan motivasi kepada mahasiswa untuk meningkatkan kemampuan dalam menulis sakubun. Pada komponen ini motivasi mengalami pula peningkatan, meskipun ada beberapa skor yang mengalami fluktuasi pada beberapa pertemuan namun hasilnya masih tetap berada pada kriteria tinggi . Selama pelaksanaan pembelajaran menulis sakubun melalui model workshop. 5) Model pembelajaran menulis sakubun melalui workshop dapat meningkatkan kemampuan menulis sakubun, juga Keaktifan setiap anggota kelompok meningkat dan lebih merata. 6) Pada komponen tanggung jawabpun demikian. Rerata skor untuk komponen tersebut hampir keseluruhan berada di atas rerata 4,5. Ini berarti bahwa model pembelajaran menulis melalui workshop dapat meningkatkan tanggung jawab mahasiswa.

\section{Pembahasan}

Tulisan mahasiswa hasil tes setiap akhir siklus telah dianalisis dengan memperhatikan kelima aspek kriteria penilaian. Kelima aspek yang dimaksud adalah isi karangan, organisasi isi, kalimat, pilihan kata, dan mekanik. Akan tetapi hasil analisisnya masih berdiri sendiri setiap siklus sehingga perkem-bangan kemampuan menulis individu mahasiswa selama siklus I, II, dan III, tidak tampak.

$$
\text { Pada siklus I, sebagian besar }
$$


mahasiswa masih belum mampu mengembangkan ide pokok dan ide pokok yang ada pun kurang relevan dengan topik dan judul yang dipilih. Akan tetapi terdapat juga mahasiswa yang telah mampu mengembangkan ide pokok karangan dengan lengkap, tetapi masih ditemukan sejumlah ketidak-jelasan. Hasil tindakan siklus I yang diperoleh dari 36 mahasiswa, menunjuk-kan sudah ada peningkatan nilai nilai tes kemampuan menulis sakubun. Jika pada tes awal (pretes) skor rata-ratanya hanya mencapai 48,06 pada tes akhir siklus I skor rata-rata sudah mencapai 53,06, dengan skor perkembangan individu 21,39. Dari hasil tindakan siklus pertama menunjukkan bahwa kemam-puan menulis sakubun belum mencapai indikator keberhasilan yang telah ditetapkan, karena skor perkembangan peningkatan kemampuan menulis sakubun mahasiswa hanya 21,39 yang dalam kriteria penilaian dalam penelitian ini masuk dalam kategori "kurang memuaskan".

Hasil tindakan siklus II yang diperoleh dari 36 mahasiswa, menunjukkan sudah ada peningkatan nilai nilai tes kemampuan menulis sakubun. Jika pada tes siklus I skor rata-ratanya hanya mencapai 54,86, pada tes akhir siklus II skor rata-rata sudah mencapai 77.44, dengan skor perkembangan individu 28,61. Dari data hasil tindakan siklus II menunjukkan bahwa kemampuan menulis sakubun belum mencapai indikator keberhasilan yang telah ditetapkan, karena skor perkembangan peningkatan kemampuan menulis sakubun mahasiswa hanya 28,61 yang dalam kriteria penilaian dalam penelitian ini masuk dalam kategori "cukup memuaskan".

Kemampuan mahasiswa pada siklus III menunjukkan hasil yang sangat baik. Hasil tindakan siklus III yang diperoleh dari 36 mahasiswa, menunjukkan hasil yang sangat baik dan memuaskan. Jika pada tes siklus II skor rata-ratanya mencapai 77,44 , namun pada tes akhir siklus III skor rata-rata sudah mencapai 90,67 Dari data hasil tindakan siklus III menunjukkan bahwa kemampuan menulis sakubun sudah mencapai indikator keberhasilan yang telah ditetapkan, karena skor perkembangan peningkatan kemampuan menulis sakubun mahasiswa 58,55 dari skor sebelumnya 28,66 yang dalam kriteria penilaian dalam penelitian ini masuk dalam kategori “ memuaskan”.

\section{SIMPULAN}

Hasil penelitian selama tiga siklus menunjukkan peningkatan nilai rata-rata kemampuan menulis siswa melalui workshop dan model kolaborasi di setiap akhir pengujian. Hasil pretest kemampuan menulis sakubun 
siswa menunjukkan nilai rata-rata $48,06 \%$, tes pada akhir siklus pertama menunjukkan nilai rata-rata 53,06\%, tes pada akhir siklus kedua menunjukkan nilai rata-rata $68,47 \%$, dan tes pada akhir siklus ketiga menunjukkan rata-rata rata-rata $82,11 \%$.

Berdasarkan indikator keberhasilan nilai rata-rata tes siswa pada akhir siklus ketiga yang mencapai $82,11 \%$ menunjukkan bahwa dengan menggunakan kolaborasi dan lokakarya pembelajaran sakubun dapat meningkatkan kemampuan menulis mata pelajaran siswa.

\section{PUSTAKA RUJUKAN}

Akhadiah, Sabarti. Materi Pokok Menulis $1: 1$ - 9; PISA4239/3 SKS. Jakarta:

Universitas Terbuka, 2001.

Akiyama, Yoshihiko. Kakeru Sakubun Geemu 18-sen. Tokyo: Meiji Tosho. 2007.

Alwasilah, A. Chaedar \& Senny Suzanna. Pokoknya Menulis: Cara Baru Menulis dengan Metode Kolaborasi. Bandung: PT. Kibtal Buku Utama, 2007.

Anshori, Dadang. Kemampuan Menulis Mahasiswa, Jurnal. Universitas Pendidikan Indonesia, 2004.

Arikunto, Suharsini, Penelitian Tindakan Kelas. Jakarta: PT Bumi Aksara, 2006.

Aunnurahman, Belajar dan Pembela-jaran, Bandung: Alfabeta, 2009.
Brady Laurie, Models and Methods of Teaching. Australia: Pratice-Hall of Australia Pty Ltd, 2005.

Cresswell, John W. Educational Re-search, London: Pearson, 2008.

Cresswell, John W. Research Design:Qualitative, Quantitative, and Mixed Methods Approa-ches. SAGE Thousand Oaks California, 2009.

Dimyati dan Mudjiono, Belajar dan Pembelajaran, Jakarta: Rineka Cipta, 1999.

Elliot Jhon, Action Research for Educational Chance: Philadel-phia: Open University Press, 1991.

Emzir. Metodologi Penelitian Pendidikan: Kuantitatif \& Kualitatif. Jakarta: PT. RajaGrafindo Persada, 2008.

Furukawa, Toshiko \& Takeshi Kitamura. Jugyou no Hinto: Shokyuu Jugyou no Hinto: Sakubun no Fiidobakku', dalam: Nihongo Kyouiku Tsuushin, No. 38 (edisi bulan September). Urawa: Nihongo Kokusai Sentaa, 2000b.

Hatasa, Kazumi. Nihongo Kyoushi no tame no IT Riterashii Nyuumon. Tokyo: Kuroshio Shuppan, 2002.

Hopkins, David. A Teacher's Guide to Classroom Research. Philadelphia: Open University Press, 2002. 
Huda, Miftahul, Cooperative Learning, Metode, Teknik, Struktur dan Model Pembelajaran, Pustaka Pelajar, 2011.

Ikeda, Nobuko. CALL. dоипуии to kaihatsu to jissen: Nihongo Kyouiku de no konpyu-ta no katsuyou. Kuroshio shuppan.

Joice B dan Weil. M, Models of Teaching,Boston: Allyn and Bacon, 2000.

Kayo, Sato. 'Mareeeshiago Washa ni Taisuru Nihongo Sakubun no Ichishidouhou, dalam: Nihon Daigaku Daigakuin Sougou Shakai Jouhou Kenkyuuka Kiyou, No.6, 267-277, 2005.

Kemmis, Stephen dan Mc Taggart, Robbin. The Action Research Planner. Victory: Deakin University Press, 1988.

Killen, R. Effectife Teacing Stratigies, Lesson from Research and Practice. Australia: Social Science Press. 1998.

Krashen, S.D. Writing, Research, Theory and Application. New York: Pergamon Institute of English, 1989.

Langer, Applebee. Writing In The

Secondary School. NTCE Research Report, 1981.
Lucy McCormick Calcins, The Art of

Writing. Portmouth: New Hamshire, 1989.

Lucy McCormick Calcins dan Shelley Harwayne, The Writing Workshop:

A Word of Differenc. Pourtmouth: Heinemann, 1987

Luschie, Thomas. Action Research in Universities and classroom jurnalLearning system Institute-Florida State University US, 2009.

Mills, Geoffrey. A Guide for The Teacher Researcher. Ohio: Merril, an imprint of Prentice Hall International, Inc, 2000.

Mimaki, Youko. Tokyo: Nihongo Kyoujuhou o Rikai Suru Hon: Jissenhen (Kaisetsu to Enshuu). Babell Press, 2005.

Nunan, David. Language Teaching Methodology: A Textbook for Teacher. Sydney: Macquarie University, 2000.

Nurgiyantoro, Burhan. Penilaian dalam Pengajaran Bahasa dan Sastra. Yogyakarta: BPFE-Yogyakarta, 2001.

Reberu Sakubun', dalam: Nihongo Kyouiku Tsuushin, No. 37 (edisi bulan Mei). Urawa: Nihongo Kokusai Sentaa, 2000a.

Rusman, Model-Model Pembelajaran Mengembangkan Profesionalisme 
Guru, Jakarta: PT. RajaGrafindo Persada, 2011

Sagala, Syaiful. Konsep dan Makna Pembelajaran. Bandung: Alfabeta, 2010.

Sharan, Shlomo, Cooperative Learning, Imperium, 2009.

Slavin, Robert E. Cooperative Learning: Teori, Riset dan Praktik. Terjemahan oleh Lita. Bandung: Nusa Media, 2009

Stringer, Ernest T, Action Research, Australia: Curtin University of Technology, 2007.

Sugiono, Metodologi Penelitian Kuantitatif dan Kualitatif. Bandung: Alfabeta, 2008.

Sutedi, Dedi. 'Teknik Menulis Kolaborasi sebagai Inovasi dalam Pembelajaran Sakubun', dalam: Jurnal Pendidikan Bahasa Jepang ASPBJI Korwil Jabar, Vol. 4, No. 1, edisi Juni 2008, hal. 34-42, 2008.

Tarigan, H.G, Menulis sebagai suatu keterampilan Berbahasa, Bandung: Angkasa, 1986.

The Japan Foundation. Kyoukasho o Tsukurou: Renshuuhen 1. Urawa: Kokusai Kouryuukikin Nihongo Kokusai sentaa, 2002.

Tiedt, I.M. Writing From Topic to Evaluation. London: Allin and Bacon, 1989.
Umemura, Osamu. 'Ryuugakusei no Nihongo Sakubun Shidou ni Tsuite no Oboegaki', dalam: Teikyo Daigaku Bungakubu Kiyou Kyouikugaku. No. 27, 2002.

Uno, Hamzah. Model Pembelajaran: Menciptakan Proses Belajar Mengajar yang Kreatif dan Efektif. Jakarta: Bumi Aksara, 2009. 